\section{In the aftermath of war}

(1)

\section{By Sarah Wagner}

\section{To Know Where He Lies: DNA Technology and the Search for Srebrenica's Missing}

University of California Press, 2008

352 pp., hardcover, \$55

ISBN 9780520255746

\section{Reviewed by Jay D Aronson}

When Bosnian Serb forces overran the UN 'safe area' at Srebrenica in July 1995, the international community stood by as the Bosniak (Bosnian Muslim) population there was thrown into a state of terror. Bosniak men and boys either sought refuge with their families at Potocari, the headquarters of the impotent Dutch-led UN peacekeeping force, or set off in the woods on a futile expedition toward the city of Tuzla, some 50 kilometers away. No matter which choice they made, the outcome was the same for more than 8,000 men and boys: a brutal death at the hands of Bosnian Serb forces, then hasty burial in mass graves with dozens or hundreds of their brethren.

Despite their inaction during this massacre, when relative calm was restored to the region by the Dayton Peace Agreement in late 1995, the international community rushed in to help rebuild the region's infrastructure and repair its social fabric. Anthropologist Sarah Wagner examines an important aspect of this post-conflict reconstruction in detail in her compelling new book on the use of DNA analysis by the newly created International Commission on Missing Persons (ICMP) to locate and identify missing Bosniak males. She does so from the perspective of someone who is at ease in the laboratory, the homes of the ordinary Bosniaks, and the contested political terrain of Bosnia and Herzegovina. Among her many qualifications are fluency in the regional language, formerly known as Serbo-Croatian but now the subject of a nomenclature dispute, and the fact that she spent more than a year in Bosnia conducting fieldwork.

Wagner's book begins with an overview of the history of Bosnia and Herzegovina, in particular emphasizing the events that led to the July 1995 genocide and the socio-political settlement that emerged at Dayton. Subsequent chapters focus on the actual identification process, the impact of these identifications on the people and communities of Bosnia, the commemoration and memorialization of the massacre, plus the many ways that the unique technological system developed in Bosnia has traveled to various disaster sites around the world. Particularly in the final chapter, she advances the claim that post-conflict DNA

Jay D. Aronson is in the Department of History, Carnegie Mellon

University, Pittsburgh, Pennsylvania 15213, USA.

e-mail:aronson@andrew.cmu.edu identification is a technology of social repair that is predicated on Western liberal notions of the primacy of the individual.

As Wagner details, the effort to identify the victims of Srebrenica posed significant technical challenges. In the months after the massacre, Bosnian Serb forces sought to cover up their crimes by digging up mass graves and reburying the contents haphazardly at secondary sites. This meant that the remains of victims were torn from the physical contexts of their deaths (which provide the clues that forensic scientists traditionally use to investigate a crime scene) and body parts of a given individual were often spread over two or more locations.

There were also strong political impediments to the identification effort. The decentralized governance structure put into place at Dayton left part of Bosnia and Herzegovina controlled by Bosniaks and Croats (the Federation of Bosnia and Herzegovina), and the other part (the Republika Srpska) controlled by Bosnian Serbs. Because Srebrenica was deep within the Serb-controlled section of the country, Federation authorities would require the official cooperation and support of the leaders of the Republika Srpska in their efforts to recover and identify the victims of Serb aggression. This was an untenable situation and made an organization like ICMP necessary.

Although this book is useful for anyone interested in the aftermath of war and human rights violations, it offers several crucial lessons to the scientists who feel compelled to get involved in humanitarian DNA identification efforts, only three of which I will mention here.

The first is that despite claims of objectivity, DNA identification does not exist in a social and political vacuum - scientific activities become implicated in pre-existing disputes and often reshape the social and political landscape in important ways, for example, by validating or underwriting particular versions of history and by empowering certain groups to take control of their situation and demand political action.

Second, DNA identification is only one part of the recognition that reattaches identity to mortal remains. Thus, technology is the starting point, not the end point, of the process. DNA matches are always probabilistic (because they are matches between remains and family members) and often need to be confirmed by more traditional investigatory techniques. Further, in order to be made official, they must be formally accepted by family members. This means that trust, both in the institution and the evidence that it creates, is central to the identification process.

Third, Wagner demonstrates that the meaning of an individual identification in Bosnia is multivalent. It means something very different, often contradictory, to families, communities, nationalist and religious leaders of various persuasions, and the international community.

Wagner has done an extraordinary job of documenting the effort to identify the victims of the Srebrenica genocide in a sensitive manner. The only shortcomings of her book are those that emerge from her disciplinary training, and they are more than understandable given the context of her work. It is abundantly clear that Wagner empathizes most with the female relatives whom she came to know during the time that she spent in Bosnia and tells the story primarily from their perspective. Although this gives her incredible insight into the human drama of the identification process, it means that the broader political and institutional dimensions of the story often get less attention than they deserve. 